\title{
Ege ve Akdeniz Kıyılarında Deniz Suyu Sıcaklıkları İçin Soğuma Döneminde Trend Analizleri
}

\section{Eyüp Şişman ${ }^{1, *}$}

${ }^{1}$ İstanbul Medipol Üniversitesi, Mühendislik ve Doğa Bilimleri Fakültesi, İnşaat Mühendisliği Bölümü, Kavacık, 34810, İstabul.

\section{Özet}

Eğilim araştırmalarında regresyon analizi ve sıklıkla kullanılan Mann-Kendall (MK) yöntemi gibi klasik yaklaşımlar kısıtları ve varsayımları sebebiyle bağlayıcı şartları ve ürettikleri bilgi açısından da ihtiyacı karşılayamamasına bağlı olarak yavaş yavaş terk edilmektedirler. Eğilimler için regresyon yaklaşımının kullanılabilmesi ve doğru sonuçlar alınabilmesi için verilerin normal dağılıma uyması, iç bağımlılık (otokorelasyon) olmaması, ölçümlerin hatasız olması, eşit varyans, doğrusallık kabullerinin her birinin analiz öncesinden araştırılması gerekir. Mann-Kendall yöntemi içinde buna benzer zorluklar olup, sonuçları açısından eğilim yok, artan eğilim veya azalan eğilim şeklinde kisıtlı bilgi üretilmektedir. Bu zorluk ve eksiklere iyi bir seçenek olarak geliştirilen herhangi bir varsayıma bağll olmadan doğrudan uygulanabilen Yenilikçi Eğilim Ç̈zümlemesi (YEC) (Sen, 2012) yöntemi ve algoritması bu çalışmada temel alınarak, deniz suyu sicaklık verilerindeki eğilim ve bu eğilimin matematik formu incelenmiştir. Ortaya konulan model ile farklı istasyonlardaki ortalama eğilim gidişleri klyaslanabilmiştir. Yapılan çözümleme sonucunda, 1960-2009 yılları arasında 4 istasyonda Eylül ayından Şubat ayına kadar kaydedilen deniz suyu sıcaklık verilerinde, 2000-2009 dönemine doğru artış eğilimi görülmektedir. Özellikle iklim değişikliğinden en fazla etkilenecek bölge olan Akdeniz için, 2000-2009 sürecindeki eğilim çok dikkat çekicidir. Ancak, model grafikleri incelendiğinde, referans yll olarak seçilen 1960-1969 yllına göre 4 farklı süreçte (1970-1979, 19801989, 1990-1999, 2000-2009) ortaya çıkan azalma ĕgilimleri, iklim değişikliği gerçeğine bağlı olarak, 1960-1969 yllları verilerinin tarafsızlı̆̆ının sorgulanmasını akla getirmektedir.

$\underline{\text { Anahtar Sözcükler }}$

Trend Analizi, Deniz Suyu Sıcaklığı, Yenilikçi Eğilim Çözümlemesi, Türkiye

\section{Trend Analysis for the Cooling Period for Sea Water Temperatures in Aegean and Mediterranean Coasts}

\begin{abstract}
In trend studies, classical approaches such as regression analysis and frequently used Mann-Kendall (MK) methods are bound to lose their usage due to their limitations and assumptions, due to their inability to meet their requirements in terms of binding conditions and knowledge. In order to use the regression approach for the trends and to obtain correct results, the data should fit into normal distribution, there is no internal dependency (autocorrelation), the measurements are accurate, equal variance, linearity acceptances should be investigated before each analysis. There are similar difficulties in the Mann-Kendall method, which results in no trend, increasing or decreasing trend insufficiency in engineering practices. In this study, the trends in Sea Surface Temperature (SST) and their mathematical structures are examined. The trends in different stations are compared with the suggested model. SST was recorded at four stations between 1960 and 2009.The increasing trend towards the period of 2000-2009 shows itself. The trends during of 20002009 period is especially striking for the Mediterranean region. However, when the model graphs are examined, there are decreasing trends that emerged in 4 different durations (1970-1979, 1980-1989, 1990-1999, 2000-2009) compared to the 1960-1969 duration, which was selected as the reference year. Depending on the reality of climate change, the neutrality of the observed data 1960-1969 should be questioned.
\end{abstract}

$\underline{\text { Keywords }}$

Trend Analysis, Sea Surface Temperature, Innovative Trend Analysis, Turkey

\section{Giriş}

Günümüzde çok fazla enerjiye ihtiyaç duyulması ve bunun büyük bir bölümünün fosil yakıt kaynaklarından temini, sera gazlarının daha fazla salınmasına ve hidrolojik çevrimde değişimlere sebep olmaktadır. Sera gazlarının atmosferde toplanmasıyla süregelen yapının değişmesi, olağan dengeleri de etkilemiş ve daha fazla kararsızlıklar ortaya çıkmaya başlamıştır. Bu karasızlıklar doğa olaylarında sürekli yeni uç değerlerin (rekorların) görülmesine ve her gün geleceğin geçmiş deneyimler üzerinden planlanmasını ve öngörüleri zorlaştırmaktadır. Tüm bu değişimler hidrolojik ve meteorolojik verilerde sistematik, artan ve/ya azalan eğilimler şeklinde kendini göstermektedir. 
Araştırmalarda model girdileri olarak değerlendirilen yağış, buharlaşma, akış, sıcaklık gibi verilerin sera gazlarındaki artış ile olağan durumlarının değiştiği, sistematik artış ve/veya azalış eğilimlerinin olduğu gözlemlerle ve kullanılan modeller ile açıklanmaktadır. Eğilim modelleri ve ayrıntılı çözümlemeleri (analizi) mühendislik, sağlık, ekonomi vb., çoğu alanda planlamalar, tahmin ve öngörüler için gereklidir. Buna bağlı olarak eğilim konusunda literatür incelemesi yapıldığında çok fazla sayıda yöntemin geliştirildiği görülmektedir. Yapılan araştırma ve çalışmalar ayrıntılı incelendiğinde, eğilim (trend) çözümlemesi, eğilim yönelimi (artan, azalan veya trend yok) ve az sayıda da eğilim büyüklükleri üzerine yoğunlaştırdığı görülmektedir.

İlk çalışmalara bakıldığında, verilerdeki artış ve/veya azalışların belirlenmesi için bazı temel yöntemler ön plana çıkmaktadır (Mann 1945; Kendall 1975; Sen 1968; Haan 1977). Araştırmacılar bu klasik çalışmaları ve bunların temelinde geliştirilen yöntemleri hidrolojik ve meteorolojik verilerin eğilim çözümlemeleri için uzun yıllardır kullanmaya devam etmektedir (Taylor ve Loftis 1989; Chiew ve McMahon 1993; Burn 1994; Hamed ve Rao 1998; Helsel ve Hirsch 2002; Jhajharis 2009; Nalley vd. 2013; Jones vd. 2015). Bu yöntemler ile eğilim durumunun olup olmadı̆̆1 ve bulunan yönelimin ne yönde olduğu belirlenmeye çalışılmaktadır. Eğilimlerin kayda değer seviyede olmaması ve/veya kullanılan verilerin modeller için belirlenen varsayımlara uyması durumunda seçilen klasik yöntemler bir ölçüde kabul görür. Ancak gerek verilerin analiz öncesi tahkikinde varsayımların karşılanmaması ve gerekse verilerdeki ciddi artış ve/veya azalışlar klasik eğilim modelleri için eksikliktir. Bu mahzurlu durumlara karşı iklim değişikliği ile hidrolojik ve meteorolojik verilerdeki eğilim durumlarının tespitine yönelik, hızla artan araştırmalarda kolaylıkla kullanılması için, Şen (2012) tarafından herhangi bir kabule dayanmayan, basit şekilde her türlü zaman serilerine uygulanabilen Yenilikçi Eğilim Çözümleme (YEÇ) yöntemi önerilmiştir. Bu yöntem aynı zamanda her türlü eğilim durumu için görsel olarak da çok geniş ölçüde yorum ve değerlendirme imkânı vermektedir. Bu yeni temel yaklaşım kısa sürede çok sayıda araştırmacının dikkatini çekmeyi başarmıştır (Sonali ve Kumar 2013; Markus 2013; Şen 2014; Saplioglu vd 2014; Dabanl1 vd. 2016; Öztopal ve Şen 2017; Tabari vd. 2017; Mazroui vd. 2017; Cui vd. 2017; Güçlü vd. 2018; Alashan 2018; Güçlü 2018).

IPCC iklim değişikliği konusundaki çalışmalarda, deniz suyu sıcaklarının tanımlanmasının çevresel parametreler içerisinde en önemlilerinden biri olduğunu belirtmektedir (Houghton vd. 1996). Denizlerle çevrili Türkiye ve benzeri yerleşim alanlarında, iklim değiş̧ikliğinin ortaya çıkardığı ve/ya çıkaracağı olumsuzluklar ve fırsatların daha iyi görülebilmesi ve değerlendirilebilmesi açısından, deniz suyu sıcaklık verilerindeki eğilimlerin ayrıntılı şekilde çözümlenmesi (analiz edilmesi) ve bilinmesi hidroloji, meteoroloji, tarım, hayvancılık, turizm vb. çeşitli alanlar ve sektörler için çok önemli ve aynı zamanda gereklidir. Deniz suyu sıcaklıklarındaki değişimlerin ve eğilimlerinin ayrıntılı şekilde değerlendirilmesi, ileride yağış, evapotranspirasyon, rüzgâr hızı, nem, sıcaklık verileri ile uğraşan hidroloji, hidrometeoroloji ve hidroklimatoloji alanlarına da önemli katkılar sağlayacaktır. Deniz suyu sıcaklıkları eğilimleri konusunda çeşitli yöntemler kullanılarak gerçekleştirilmiş çok çalışma mevcuttur (Revelle 1983; Kaplan vd. 1998; Robertson vd. 2002; Kazmin and Zatsepin 2007; Deser vd. 2010; Zveryaev 2015; Park vd. 2015; Ozgenc 2017).

Literatürü incelediğimizde eğilim değerlendirmesiyle ilgili ayrıntılı sözel bilgiler üreten yaklaşımların olmadığı, YEÇ ile eğilimler konusunda sözel yorumların da arttığı görülmektedir. Literatür araştırması sonucunda bir değerlendirme yapıldığında, doğru yöntemler tercih edilerek eğilimin yönelimi ve büyüklüğünün sağlıklı şekilde ortaya konulması durumunda, verilerdeki saklı bilgilerin ortaya çıkarılması kolaylaşmakta, daha faydalı ve nesnel bilgiler elde edilebilmektedir. Bu çalışmanın amacı iklim değişikliği açısından çok önemli bir gösterge olan deniz suyu sıcaklıklarındaki eğilimi ortaya koyarak, ortalama eğilimin nesnel şekilde ifadesi için fonksiyonel bağıntının matematik ifadesinin araştırılmasıdır. Bunun için YEÇ algoritmasından faydalanılarak eğilim fonksiyonları belirlenmiş ve regresyon kuralları yardımıyla eğilim saçılımlarına en uygun matematiksel ifadeler çıkarılmıştır. Bu çalışmada Ege denizi kıyısında İzmir ve Bodrum'da Akdeniz kıyısında Fethiye ve İskenderun'da uzun dönemli deniz suyu sıcaklık verilerinden faydalanarak Eylül ayından Şubat ayına kadar soğuma süresi için eğilimler parçalı YEÇ ile detaylandırılmıştır.

\section{2. Çalışma Alanı ve Veriler}

Türkiye'nin batı ve güney kıyılarının Akdeniz havzasına uzaklıkları ve uzun kıyı şeridi dikkate alınarak, Akdeniz ve Ege'de seçilen istasyonlarda deniz suyu sıcaklıklarındaki eğilimler bu çalışmada araştırılmıştır. Türkiye'nin batısında yer alan Ege denizi yaklaşık 2,805 km ile en uzun kıyı şeridine sahiptir. Akdeniz ise 1,577 km kıyı uzunluğu ile, ülkenin çevresindeki dört farklı ekolojiye sahip deniz içerisinde, üçüncü sıradadır. İklim değişikliğine bağlı eğilim araştırmaları için seçilen 4 istasyonun 1960-2009 yılları arasında kayıtlı verileri kullanılarak çözümlemelerde bulunulmuştur. Bu çalışmadaki istasyonların yaklaşık konumları Şekil 1'de görülmektedir. 


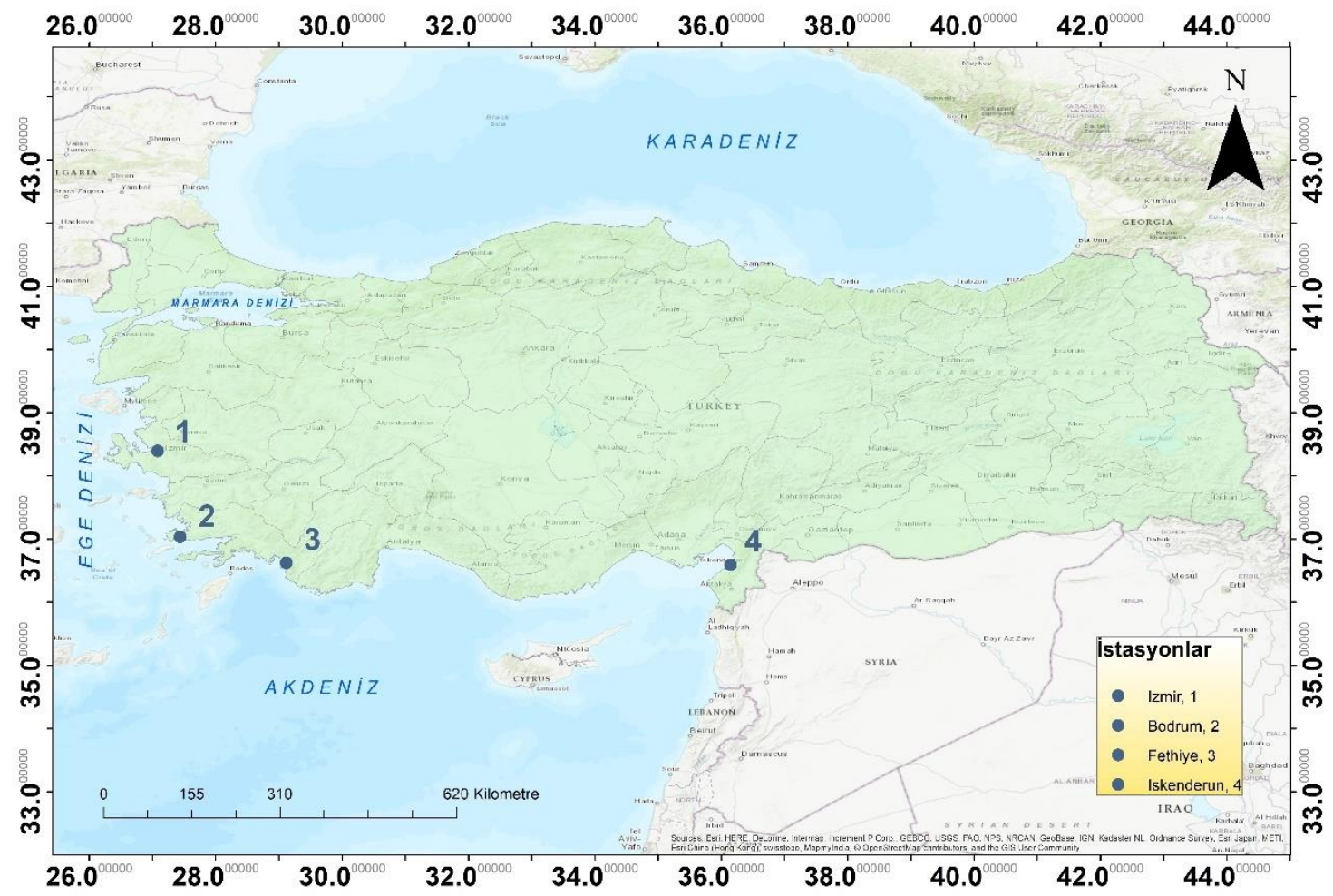

Şekil 1: Deniz suyu sıcaklık ölçümü gözlem istasyonları yerleşim haritası

İstasyonlara ait konum bilgileri Tablo 1'de ve 1960-2009 yılları arasında kaydedilen deniz suyu sıcaklıklarına ait tanımlayıcı istatistik bilgiler (ortalama sıcaklık, minimum sıcaklık, maksimum sıcaklık, varyasyon katsayısı, çarpıklık katsayısı, sivrilik-basıklık katsayıları) Tablo 2'de verilmiştir.

Tablo 1: İstasyon Yerleşim Bilgileri

\begin{tabular}{ccccc}
\hline \hline İstasyon No & İstasyon İsmi & Kıy1 & Enlem & Boylam \\
\hline $1(17220)$ & İzmir & \multirow{2}{*}{ Ege } & 38.3949 & 27.0819 \\
$2(17290)$ & Bodrum & \multirow{2}{*}{ Akdeniz } & 37.0328 & 27.4398 \\
\hline $3(17296)$ & Fethiye & 36.6264 & 29.1239 \\
$4(17370)$ & İskenderun & & 36.5888 & 36.1548 \\
\hline \hline
\end{tabular}

Seçilen istasyonların verileri incelendiğinde Şubat ayında ortalama deniz suyu sıcaklıkları en düşük olup, Ağustos ayına gelindiğinde en yüksektir. Şubat’tan Ağustos'a deniz suyu sıcaklıkları sürekli artış gösterirken, Eylül ayından Şubat ayına sürekli azalış görülmektedir. Isınma ve soğuma periyotlarının davranışları dört istasyon içinde benzer olup, birim zamandaki artış ve azalış miktarları aylık değişmektedir. Bölgesel ısınma ve soğuma eğilimlerinin enlem ve boylama göre farklılıkları tanımlayıcı istatistiklerden yorumlanabilmektedir. Ortalama, maksimum, minimum ve varyans istatistikleri incelendiğinde deniz suyu sıcaklık verilerindeki değişim aralığı açısından her istasyonun karakteristiğinin farklı olduğu görülmektedir. İstasyonlar içerisinde İzmir'de yıllar arasında Mayıs ayında deniz suyu sıcaklıklarındaki dalgalanma istatistiklerden anlaşılmaktadır. 50 yıllık süreçte Mayıs ayı için minimum ve maksimum sıcaklıklar arasında yaklaşık 10 derecelik bir fark gözlenmiştir. Varyans parametresi de Mayıs ayında ortaya çıkan bu değişimi doğrulamaktadır. İzmir en fazla değişimin görüldüğü istasyondur. Minimum, maksimum ve varyans katsayıları incelendiğinde yıllar içerisinde ortalama ile temsil açısından en dengeli (stabil) istasyon Fethiye olarak ön plana çıkmaktadır. Çarpıklıklar açısından değerlendirme yapıldığında Ege ve Akdeniz istasyonları için dikkat çekici durum Ege'de negatif çarpıklık değerleri fazla iken, Akdeniz' deki istasyonlarda ise sıfıra daha yakın pozitif çarpıklıklar görülmektedir. Bu durum İzmir ve Bodrum istasyonlarındaki deniz suyu sıcaklıklarının genelde uzun yıllar ortalamaların üzerinde olduğunu, Akdeniz'de ise genelde uzun dönem ortalamalarına yakın veya altında sıcaklıklar olduğunu belirtir. 
Tablo 2: Seçilen istasyonların deniz suyu sıcaklıkları istatistikleri

\begin{tabular}{|c|c|c|c|c|c|c|c|c|c|c|c|c|c|}
\hline \multirow{2}{*}{ İstasyon İsmi } & \multirow{2}{*}{$\begin{array}{l}\text { İstatistik } \\
\text { iparemetreler }\end{array}$} & \multicolumn{12}{|c|}{ 1960-2009 yıllarına ait uzun dönem aylık ortalama deniz suyu sıcaklıkları $\left({ }^{\circ} \mathrm{C}\right)$} \\
\hline & & Ocak & Şubat & Mart & Nisan & Mayıs & Haziran & Temmuz & Ağustos & Eylül & Ekim & Kasim & Aralık \\
\hline \multirow{6}{*}{ 志 } & Ort & 11.36 & 10.91 & 12.22 & 15.25 & 19.62 & 24.09 & 26.41 & 26.47 & 24.58 & 21.40 & 17.26 & 13.70 \\
\hline & Min & 9.30 & 8.40 & 10.10 & 11.30 & 13.80 & 19.40 & 25.00 & 24.40 & 23.00 & 19.00 & 14.60 & 11.90 \\
\hline & Maks & 14.00 & 12.90 & 14.30 & 17.40 & 23.10 & 25.90 & 27.70 & 28.60 & 26.20 & 23.10 & 20.00 & 16.60 \\
\hline & Varyans & 1.54 & 1.13 & 1.40 & 1.69 & 2.67 & 1.32 & 0.48 & 0.86 & 0.47 & 0.71 & 1.31 & 1.42 \\
\hline & Basıklık & -1.01 & -0.49 & -1.10 & 1.05 & 5.14 & 6.14 & -0.17 & -0.16 & 0.11 & 0.40 & 0.12 & -0.19 \\
\hline & Çarpıklık & 0.07 & -0.42 & -0.08 & -0.85 & -1.58 & -2.01 & -0.23 & -0.02 & -0.28 & -0.20 & 0.10 & 0.56 \\
\hline \multirow{6}{*}{ 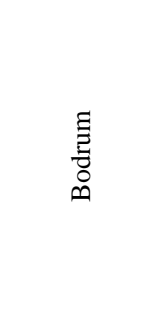 } & Ort & 16.04 & 15.46 & 15.75 & 16.82 & 18.76 & 21.14 & 22.53 & 23.57 & 23.00 & 21.65 & 19.59 & 17.42 \\
\hline & Min & 13.50 & 13.60 & 14.40 & 14.40 & 16.90 & 18.90 & 20.50 & 20.50 & 20.20 & 18.70 & 16.20 & 13.40 \\
\hline & Maks & 17.80 & 16.90 & 18.10 & 18.20 & 20.80 & 22.90 & 24.40 & 25.80 & 25.50 & 24.20 & 22.00 & 19.60 \\
\hline & Varyans & 0.71 & 0.62 & 0.51 & 0.48 & 0.66 & 0.71 & 0.80 & 1.29 & 1.07 & 1.11 & 1.15 & 0.89 \\
\hline & Basıklık & 1.01 & -0.01 & 1.04 & 2.22 & 0.25 & 0.46 & -0.42 & 0.46 & 0.65 & 0.66 & 1.19 & 6.17 \\
\hline & Çarpıklık & -0.32 & -0.43 & 0.58 & -0.91 & -0.19 & -0.20 & -0.22 & -0.36 & -0.20 & -0.39 & -0.30 & -1.09 \\
\hline \multirow{6}{*}{ 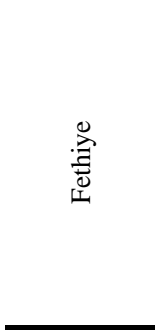 } & Ort & 16.52 & 15.89 & 16.74 & 18.75 & 22.07 & 25.12 & 27.39 & 28.45 & 26.79 & 24.08 & 21.04 & 18.19 \\
\hline & Min & 14.90 & 13.40 & 15.20 & 16.50 & 20.60 & 23.10 & 26.00 & 25.90 & 25.60 & 21.90 & 18.90 & 16.10 \\
\hline & Maks & 18.40 & 18.10 & 18.40 & 20.90 & 24.00 & 26.80 & 28.60 & 29.90 & 28.70 & 26.20 & 23.10 & 20.00 \\
\hline & Varyans & 0.67 & 0.71 & 0.56 & 0.67 & 0.68 & 0.49 & 0.39 & 0.69 & 0.45 & 0.86 & 0.88 & 0.77 \\
\hline & Basıklık & -0.07 & 1.03 & -0.14 & 0.43 & -0.75 & 1.52 & -0.44 & 0.57 & 0.23 & -0.01 & 0.07 & -0.30 \\
\hline & Çarpıklık & 0.25 & -0.15 & 0.05 & -0.07 & 0.08 & -0.64 & 0.01 & -0.69 & 0.53 & -0.18 & 0.23 & 0.26 \\
\hline \multirow{6}{*}{ 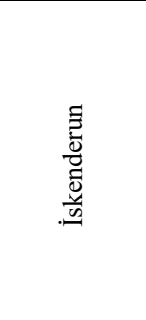 } & Ort & 15.96 & 15.32 & 16.37 & 18.50 & 22.17 & 25.93 & 28.37 & 29.18 & 28.10 & 25.30 & 21.43 & 18.06 \\
\hline & Min & 13.10 & 13.00 & 14.70 & 16.70 & 20.20 & 24.20 & 27.00 & 27.70 & 26.70 & 23.50 & 18.70 & 15.40 \\
\hline & Maks & 18.10 & 17.40 & 18.60 & 20.30 & 24.20 & 27.60 & 30.70 & 31.10 & 29.70 & 27.50 & 23.80 & 20.90 \\
\hline & Varyans & 0.98 & 1.01 & 0.53 & 0.51 & 0.85 & 0.46 & 0.52 & 0.69 & 0.55 & 0.90 & 1.67 & 1.35 \\
\hline & Basıklık & 0.23 & -0.47 & 0.76 & 0.16 & -0.40 & 0.19 & 0.82 & -0.60 & -0.65 & -0.49 & -0.60 & -0.09 \\
\hline & Çarpıklık & -0.16 & -0.09 & 0.39 & 0.05 & -0.06 & -0.04 & 0.76 & 0.40 & 0.24 & 0.35 & 0.12 & 0.42 \\
\hline
\end{tabular}

1960-2009 yılları arasında Ege Denizi ve Akdeniz istasyonlarında kaydedilen deniz suyu sıcaklık değerlerinin yorumlanması için, 50 yıllık aylık ortalamalardan çizilen grafikler Șekil 2'de verilmiștir.
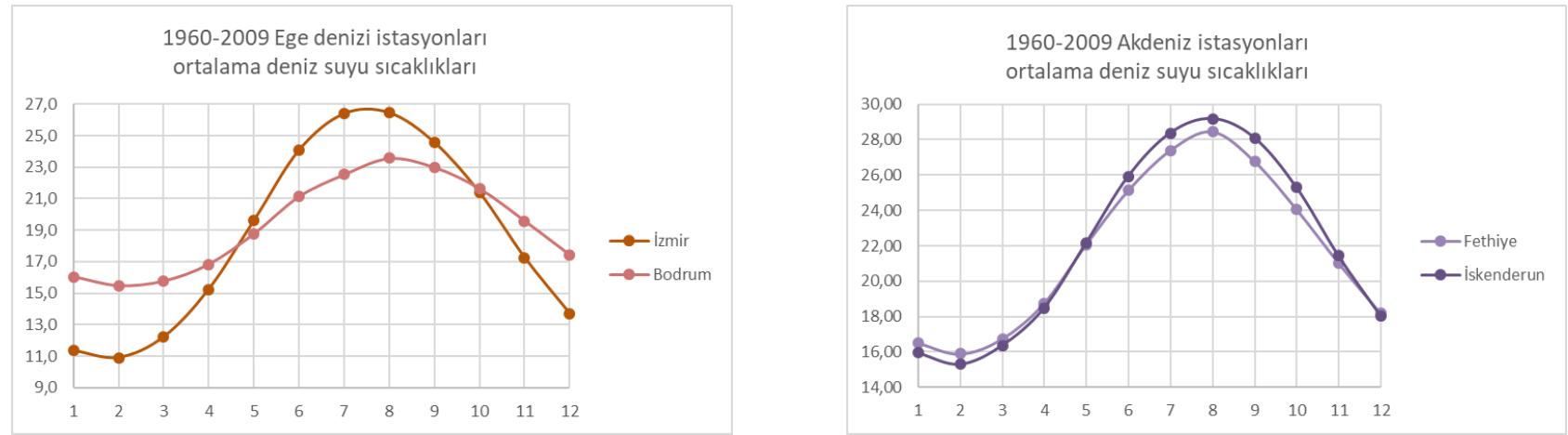

Şekil 2: Seçilen istasyonlara ait ortalama deniz suyu sıcaklıklarının değişimi (1960-2009)

Şekil 2'de görüldüğü gibi Ege denizindeki Bodrum istasyonunda Kasım ayından Nisan ayına kadar deniz suyu sıcaklıkları İzmir'e göre yüksek seyrederken, Haziran- Eylül arasında İzmir istasyonunun deniz suyu sıcaklığı Bodrum’a göre daha yüksektir. Bu durum Ege denizinde seçilen iki istasyon açısından fiziksel farklılaşmayı açıkça göstermektedir. 50 yıllık ortalamalara göre, İzmir istasyonu deniz suyu sıcaklığı 1sınma dönemi başında ortalama $10.91^{\circ} \mathrm{C}$ iken Ağustos ayında $26.47^{\circ} \mathrm{C}^{\prime}$ ye yükselmiştir. Bodrum istasyonunda ise ortalama $15.46^{\circ} \mathrm{C}^{\prime}$ den ancak $23.57^{\circ} \mathrm{C}^{\prime}$ ye çıkabilmektedir. 
Şekil 2'den ayrıca ortalama deniz suyu sıcaklıklarının Mayıs ve Ekim ayında İzmir ve Bodrum'da birbirine en yakın olduğu dönem olduğu anlaşılmaktadır. Akdeniz'de seçilen iki istasyonda ise sıcaklık değerleri ve değişimleri birbirine oldukça benzerdir. Tablo 2 ve Şekil 2 birlikte değerlendirildiğinde periyodik olarak aylık ortalama deniz suyu sıcaklıklarının İskenderun ve Fethiye istasyonları için birbirine çok yakın seyrettiği görülür. Analiz ve değerlendirmelerde kullanılan kaynak veriler Türkiye Meteoroloji Genel Müdürlüğü’nden (MGM) temin edilmiştir.

\section{Yöntem}

Bu çalışmada verilerdeki eğilimlerin belirlenebilmesi için ilk kez Öztopal ve Şen (2017) tarafından uygulanan parçalı YEÇ yöntemi algoritması tercih edilmiş ve seçilen dört istasyonun bu algoritma yardımıyla bulunan eğilim saçılımlarının matematik ifadeleri regresyon yaklaşımı kullanılarak kuvvet fonksiyonu şeklinde ifade edilmiştir. Elde edilen eğilim grafikleri sonrasında gidişler matematik olarak kuvvet fonksiyonları ile açıklanabildiğinden, YEÇ yönteminde sunulan şablondan küçük bir farkla, saçılımlara en uygun doğrunun görülebilmesi için grafik eksenleri değiştirilerek çifte logaritmik olarak hazırlanmıştır. Makalede kullanılan yöntemin algoritması ile matematik formüller sırayla maddeler halinde aşağıda sunulmuştur.

1. Bu çalışma için eldeki zaman serisi $\left(\mathrm{z}_{1}, \mathrm{z}_{2}, \ldots, \mathrm{z}_{\mathrm{n}}\right)$ başlangıca göre $\left\{\mathrm{p}_{1, \mathrm{n} / 5}\right\},\left\{\mathrm{p}_{2, \mathrm{n} / 5}\right\},\left\{\mathrm{p}_{3, \mathrm{n} / 5}\right\},\left\{\mathrm{p}_{4, \mathrm{n} / 5}\right\}$ ve $\left\{\mathrm{p}_{5}\right.$, $\mathrm{n} / 5\}$ şeklinde beş eşit parçaya ayrılmıştır.

$\left\{\mathrm{p}_{1, \mathrm{n} / 5}\right\}=\left\{\mathrm{z}_{1}, \mathrm{z}_{2}, \ldots, \mathrm{z}_{\mathrm{n} / 5}\right\},\left\{\mathrm{p}_{2, \mathrm{n} / 5}\right\}=\left\{\mathrm{z}_{\mathrm{n} / 5+1}, \mathrm{z}_{\mathrm{n} / 5+2}, \ldots, \mathrm{z}_{2 \mathrm{n} / 5}\right\},\left\{\mathrm{p}_{3, \mathrm{n} / 5}\right\}=\left\{\mathrm{z}_{2 \mathrm{n} / 5+1}, \mathrm{z}_{2 \mathrm{n} / 5+2}, \ldots, \mathrm{z}_{3 \mathrm{n} / 5}\right\}$

$\left\{\mathrm{p}_{4, \mathrm{n} / 5}\right\}=\left\{\mathrm{z}_{3 \mathrm{n} / 5+1}, \mathrm{z}_{3 \mathrm{n} / 5+2}, \ldots, \mathrm{z}_{4 \mathrm{n} / 5}\right\}$ ve $\left\{\mathrm{p}_{5, \mathrm{n} / 5}\right\}=\left\{\mathrm{z}_{4 \mathrm{n} / 5+1}, \mathrm{z}_{4 \mathrm{n} / 5+2}, \ldots, \mathrm{z}_{5 \mathrm{n} / 5}\right\}$.

2. Bölünme sonrası her bir parçanın verisi, küçükten büyüğe doğru sıralanmış ve sıralama sonrası, $\left\{\mathrm{d}_{1}\right\},\left\{\mathrm{d}_{2}\right\},\left\{\mathrm{d}_{3}\right\}$, $\left\{d_{4}\right\}$ ve $\left\{d_{5}\right\}$ şeklinde eşit sayıda verisi olan düzenlenmiş beş dizi elde edilmiştir.

$\left\{\mathrm{d}_{1}\right\}=\left\{\min \left(\mathrm{z}_{1, \mathrm{n} / 5}\right), \ldots \mathrm{z}_{\mathrm{i}}, \ldots, \max \left(\mathrm{z}_{1, \mathrm{n} / 5}\right)\right\}(1 \leq \mathrm{i} \leq \mathrm{n} / 5),\left\{\mathrm{d}_{2}\right\}=\left\{\min \left(\mathrm{z}_{2, \mathrm{n} / 5}\right), \ldots \mathrm{z}_{\mathrm{j}}, \ldots, \max \left(\mathrm{z}_{2, \mathrm{n} / 5}\right)\right\}(1 \leq \mathrm{j} \leq \mathrm{n} / 5)$,

$\left\{\mathrm{d}_{3}\right\}=\left\{\min \left(\mathrm{z}_{3, \mathrm{n} / 5}\right), \ldots \mathrm{z}_{\mathrm{k}}, \ldots, \max \left(\mathrm{z}_{3, \mathrm{n} / 5}\right)\right\}(1 \leq \mathrm{k} \leq \mathrm{n} / 5),\left\{\mathrm{d}_{4}\right\}=\left\{\min \left(\mathrm{z}_{4, \mathrm{n} / 5}\right), \ldots \mathrm{z}_{\mathrm{l}}, \ldots, \max \left(\mathrm{z}_{4, \mathrm{n} / 5}\right)\right\}(1 \leq 1 \leq \mathrm{n} / 5)$,

$\left\{\mathrm{d}_{5}\right\}=\left\{\min \left(\mathrm{z}_{5, \mathrm{n} / 5}\right), \ldots \mathrm{zl}_{\mathrm{l}}, \ldots, \max \left(\mathrm{z}_{5, \mathrm{n} / 5)}\right\}(1 \leq \mathrm{m} \leq \mathrm{n} / 5)\right.$

3. Referans alınan dizi ile diğer dizilerin verileri küçükten büyüğe doğru sırasıyla eşleştirilir. Bu çalışmada $d_{1}$ dizisi referans olarak belirlenmiş, en büyük (en küçük) $d_{1}$ değerine, en büyük (en küçük) $d_{2}, d_{3}, d_{4}$ ve $d_{5}$ değerleri eşleştirilmiştir. $\mathrm{Bu}$ eşleştirilen veri noktaları eksenleri aynı ölçekli çifte logaritmik koordinat sisteminde tanımlanan bir grafikte gösterilerek eğilimlere ait saçılma grafikleri hazırlanmıştır.

4. Bu grafik üzerine verilerin eğilim durumunun yorum ve değerlendirmesi için, 1:1(45) eğime sahip teorik "eğilim yok-trend yok" doğrusu yerleştirilmiştir.

5. Saçılma grafiklerinin eğilim kararları 1:1 doğrusuna göre yapılmıştır. 1:1 doğrusu boyunca ortaya çıkan saçılımlar eğilimin olmadığını gösterir. Aksi durumda Şekil 3 'te görülen eğilim durumlarından biriyle de karşılaşılabilir. Bu grafikte temsili gösterilen eğilim durumlarından farklı geometrik şekillerde ortaya çıkabilir. Verilerin tümü 1:1 doğrusuna göre üst kısmında kalıyorsa, monoton (bütüncül) artan eğilim, alt kısmında kalıyorsa monoton azalan eğilim vardır. Veri saçılımları bazen bunların dışında artan 1:1 doğrusunun üst bölgesinden altına doğru gidiş gösterebilir. Bu eğilim durumu monoton olmayan azalan eğilimi göstermektedir. 1:1 doğrusunun alt bölgesinden üste doğru gidişat ise Şekil 3' den görüldüğü gibi monoton olmayan artış eğilimini verir.

6. Saçılım eksenlerinin logaritmik olarak hazırlanması dışında, buraya kadar anlatılan tüm adımlar, parçalı YEÇ algoritması ile bire bir aynıdır. Bu çalışmada ilave olarak eğilim saçılımlarının nesnel olarak mukayesesi için ortalama eğilim durumlarını yansıtan fonksiyonel bağıntıların matematik ifadeleri elde edilmiştir.

$\mathrm{Bu}$ çalışmada analizler sonucu matematik eşitlikler ayrıca aşağıda (1) numaralı eşitlik yardımıyla verilmiştir.

$\mathrm{d}_{2,3,4,5}=\mathrm{a} \cdot \mathrm{d}_{1}^{\mathrm{b}}$ 


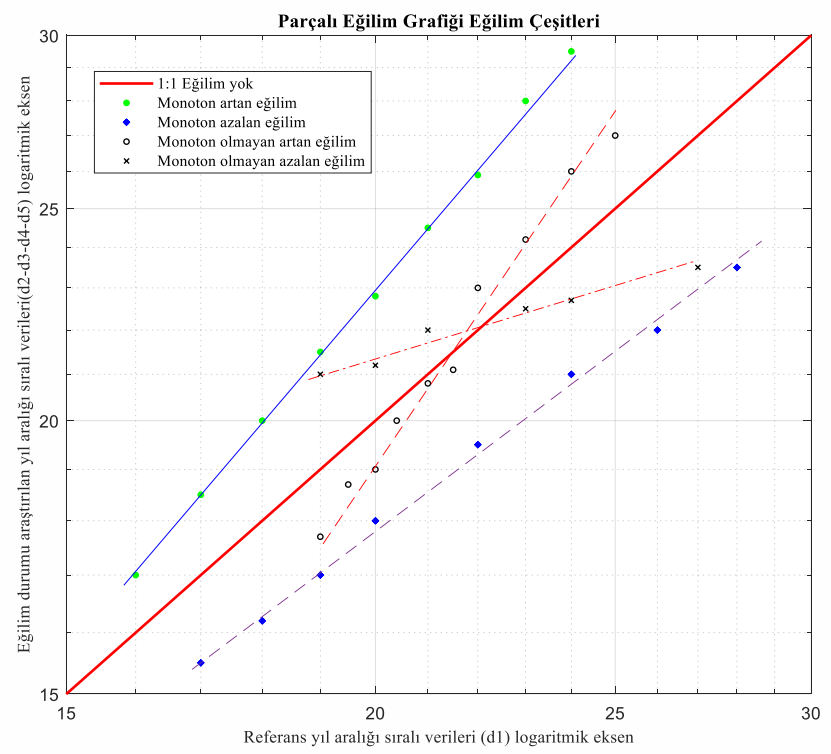

Şekil 3: YEÇ şablonuna göre eğilim durumları

\section{Uygulama}

Türkiye’nin Ege ve Akdeniz kıyılarında 1960 yılından itibaren kayıtlı verisi olan İzmir, Bodrum, Fethiye ve İskenderun istasyonlarındaki deniz suyu sıcaklıklarındaki eğilimin ortaya konulabilmesi için, bu çalışmada parçalı YEÇ yönteminden faydalanılmıştır. Modelde 1960-1969 yıllarına ait aylık ortalama veriler referans olarak alınarak ,1970 y1lından 2009 y1lına kadar olan toplam kırk yıllık süreçteki, ortalama aylık veriler onar yıllık 4 grup halinde düzenlenmiş ve referans yıllara göre her bir grubun 1970-1979, 1980-1989, 1990-1999, 2000-2009 y1llarındaki eğilim grafikleri hazırlanmıştır. Ayrıca elde edilen her bir eğilim grafiği üzerinden eğilim saçılımlarına uygun matematik fonksiyonlar çıkarılmıştır. Kullanılan algoritmalar sonucu elde edilen grafiklerdeki ortalama eğilimlerin kuvvet fonksiyonu şeklindeki matematik ifadelerine ait parametreler Tablo 3'de yer almaktadır. Grafikler incelendiğinde çifte logaritmik eksenli grafiklerde üretilen tüm regresyon doğrularının saçılımlar ile bire bir uyumlu oldukları söylenemez. Ancak Tablo 3' te görülen istatistik göstergelere (RMSE, SSE ve $\mathrm{R}^{2}$ ) göre çifte logaritmik eksende elde edilen doğrular ortalama eğilimleri yeterli seviyede açıklamaktadır. Veri saçılımlarına karşı çıkarılan matematik ifadeler belirgin (deterministik) oldukları için, eğilimlerde olabilecek rastgele durumları tam olarak açıklamaları mümkün değildir. Verilen matematik ifadeler kabul edilebilir belli bir hata terimi ile gerçeğe yakındır. Grafikler incelendiğinde kayıtlı verilerin analizine göre genelde, 2000 öncesinde 1960-1969 yılına göre azalan eğilimin olduğu, 2000 sonrası için ise özellikle sonbahar aylarında eğilimin gidişinin artış yönünde olduğu tespit edilmiştir. Ege ve Akdeniz'de seçilen ikişer istasyonun her biri için 50 yıllık veri dikkate alınarak elde edilen 4 farklı trend model grafikleri ve bu modellerin karşılaştırma grafiklerine bu bölümde yer verilmiştir. 1960-1969 10 yıllık referans yıl aralığına göre 1970-2009 yılları arasında 10'ar yıllık sürelerde 4 farklı grup için trend grafiği veri saçılımları, birbirinden farklı katsayılara sahip geometrik eğilim şeklinde ortaya çıkmıştır. Genelde, 1960-1969 yıllarına göre deniz suyu sıcaklıkları azalmıştır. İklim değişikliği etkilerinin görülmeye başlandığı özellikle 2000 yılından sonra önceki on yıllara göre kayda değer artışlar dikkat çekmektedir. 1970-1979 yılından sonra 2009 yılına kadar 4 ortalama trend model doğrusu kendi içerisinde kıyaslandığında, 2000-2009 yıllarında artış eğilimi açıkça görülmektedir. Temel yıl olarak seçilen 1960-1969 yılları verilerine göre grafiklerde ortaya çıkan azalan trend iklim değişikliği açısından beklenilmeyen bir durumdur. Ortaya çıkan bu durum yapılan bilimsel araştırma çalışmaları ile birlikte değerlendirildiğinde ilk olarak geçmiş yıllardaki ölçülen verilerin güvenilirliklerini akla getirmektedir.

Model sonuçları açısından, Bodrum için hazırlanan Şekil 4'te yer alan eğilim grafiklerinde Trend 1 modelinde, yüksek sıcaklıklarda veri saçılımları 1:1 eğilim belirleme doğrusundan açılmaktadır. Bu azalan trendin şiddetinin sıcaklık yükselmesiyle orantılı olarak arttı̆̆ını göstermektedir. 1980-1989 yıllarının 1960-1969 yılları ile kıyaslanması ile ortaya konulan Trend 2 modelinde çifte logaritmik eksende gösterilen azalan trend doğrusu 1:1 eğilim belirleme doğrusuna paralel olarak gerçekleşmiştir. Bu şekilde sonbahar ve kış aylarında yıllar içerisindeki farklı sıcaklıklarda trend azalmasının benzer oranda gerçekleştiğini göstermektedir. 1990-1999 yıllarını kapsayan Trend 3 modeline göre ise, kış aylarında azalan trend daha belirgin şekilde ortaya çıkmaktadır. Son olarak 2000-2009 yıllarına gelindiğinde, kış aylarında genelde azalan trend durumu hâkim iken, sonbahar ve kış ayları başlangıcında artan trend ortaya çıkmıştır. Yıllar itibariyle trend gelişimleri takip edilirse, 1970 yılından itibaren genel trend artış yönündedir. 

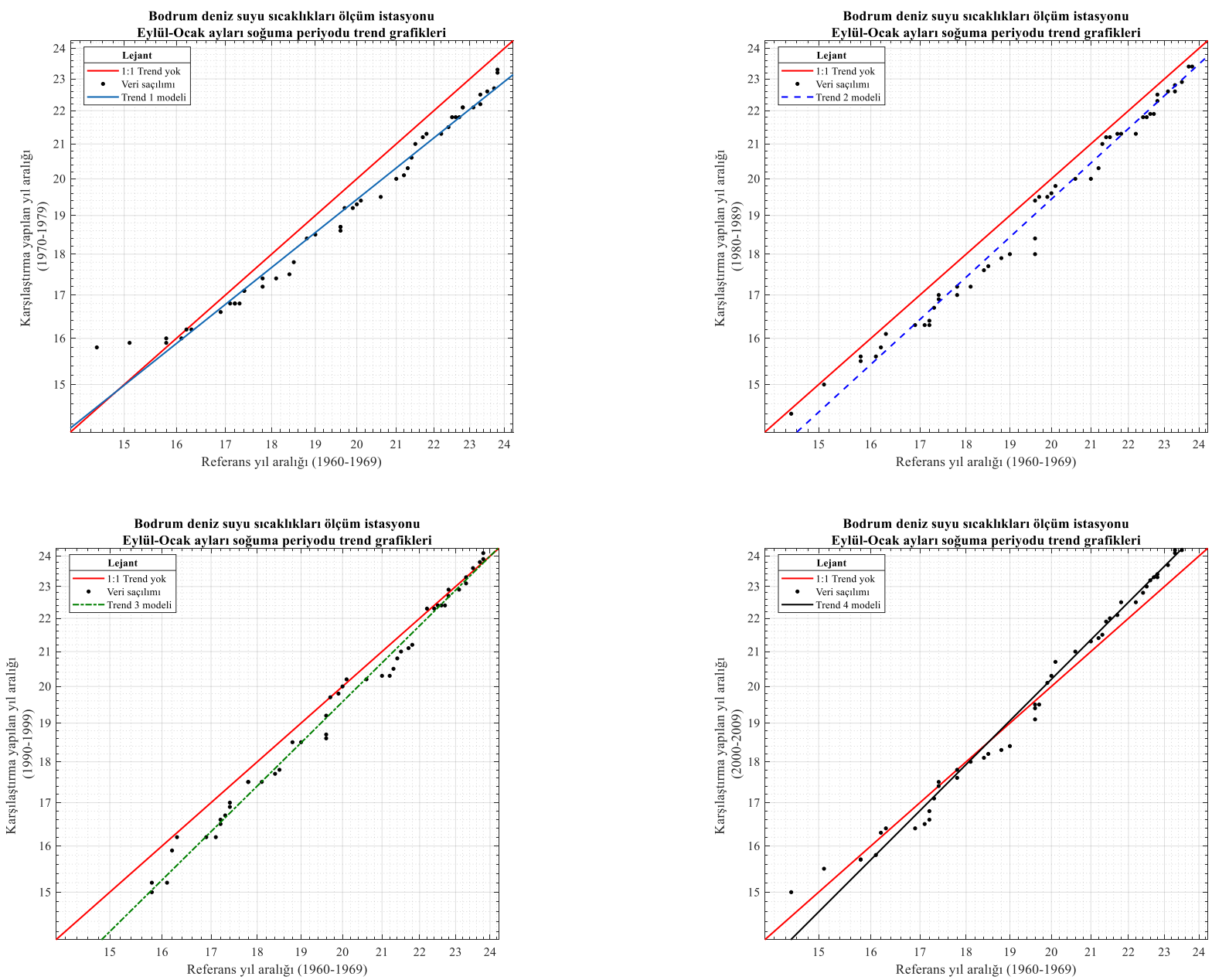

Şekil 4: Bodrum deniz suyu sıcaklıkları parçalı trend analizi grafikleri

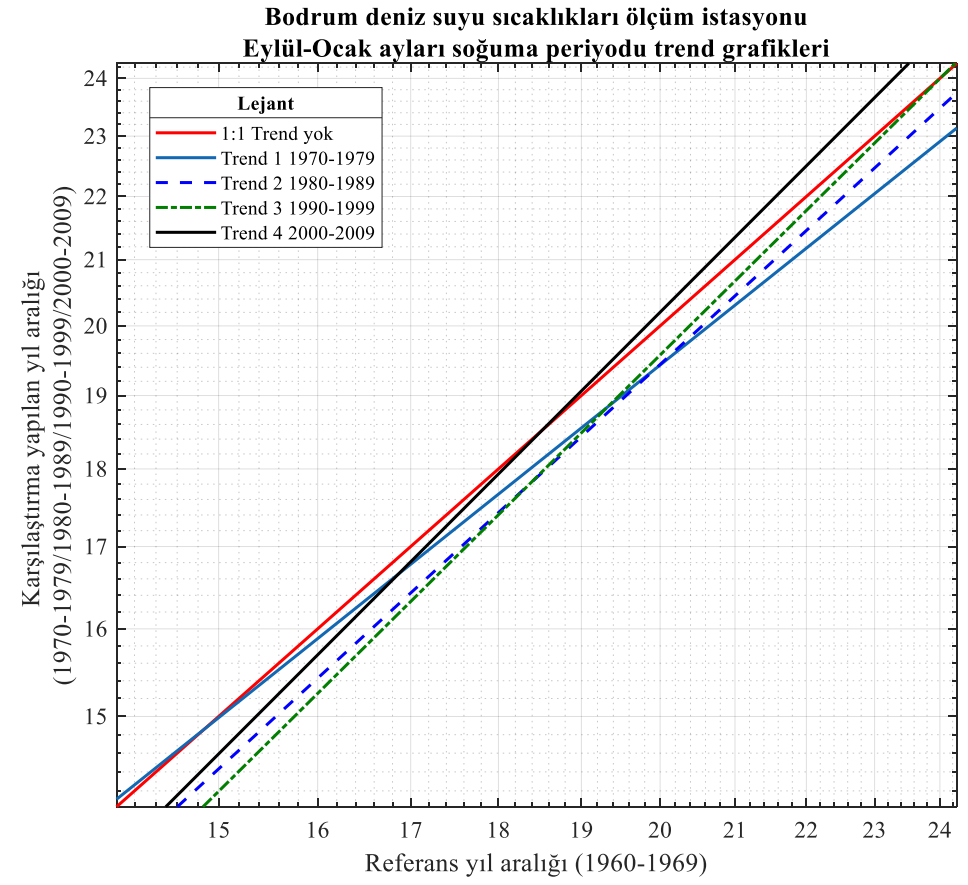

Şekil 5: Bodrum deniz suyu sıcaklıklarının 1960-1969 referans yıl aralığına göre eğilimleri 

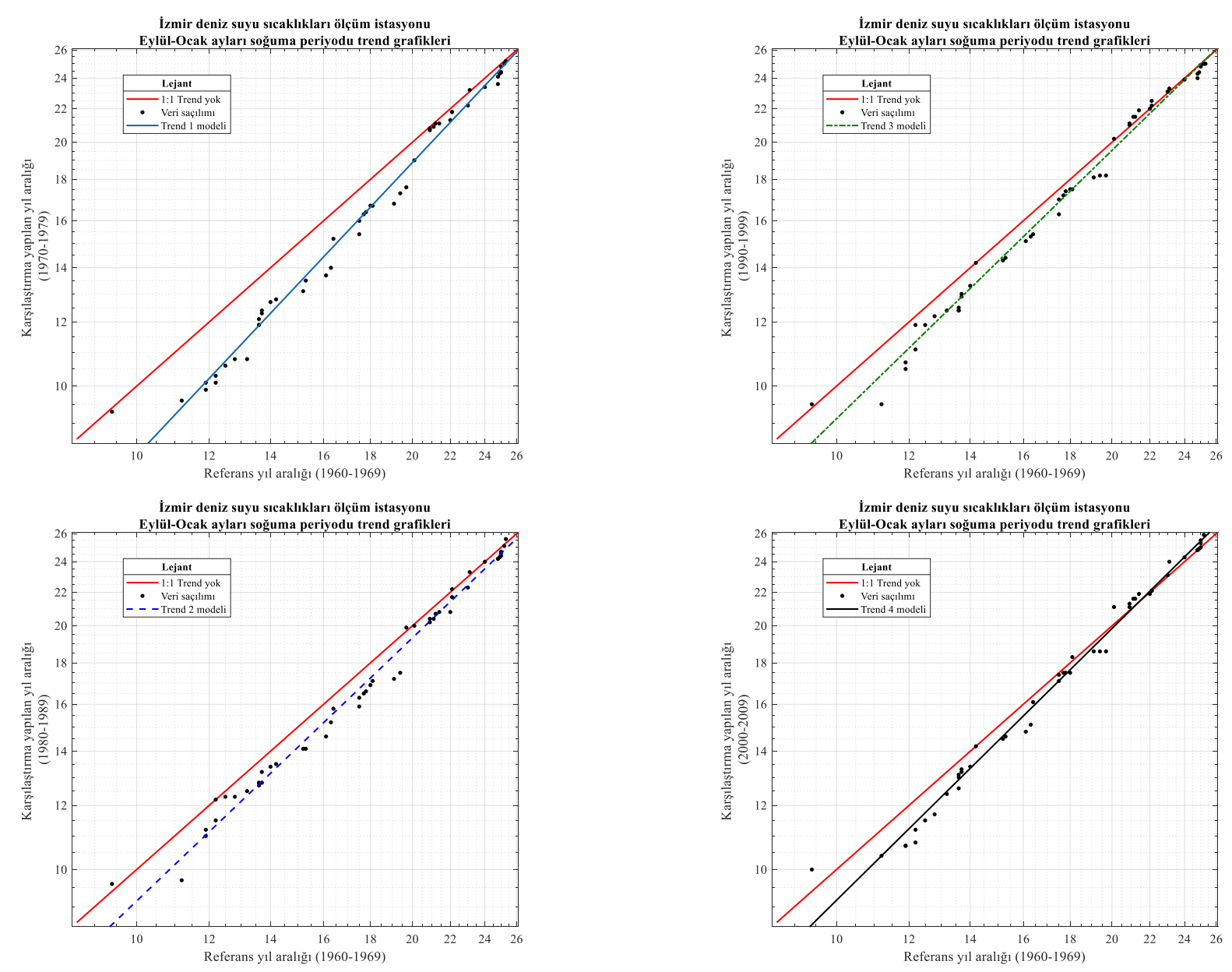

Şekil 6: İmir deniz suyu sıcaklıkları parçalı trend analizi grafikleri

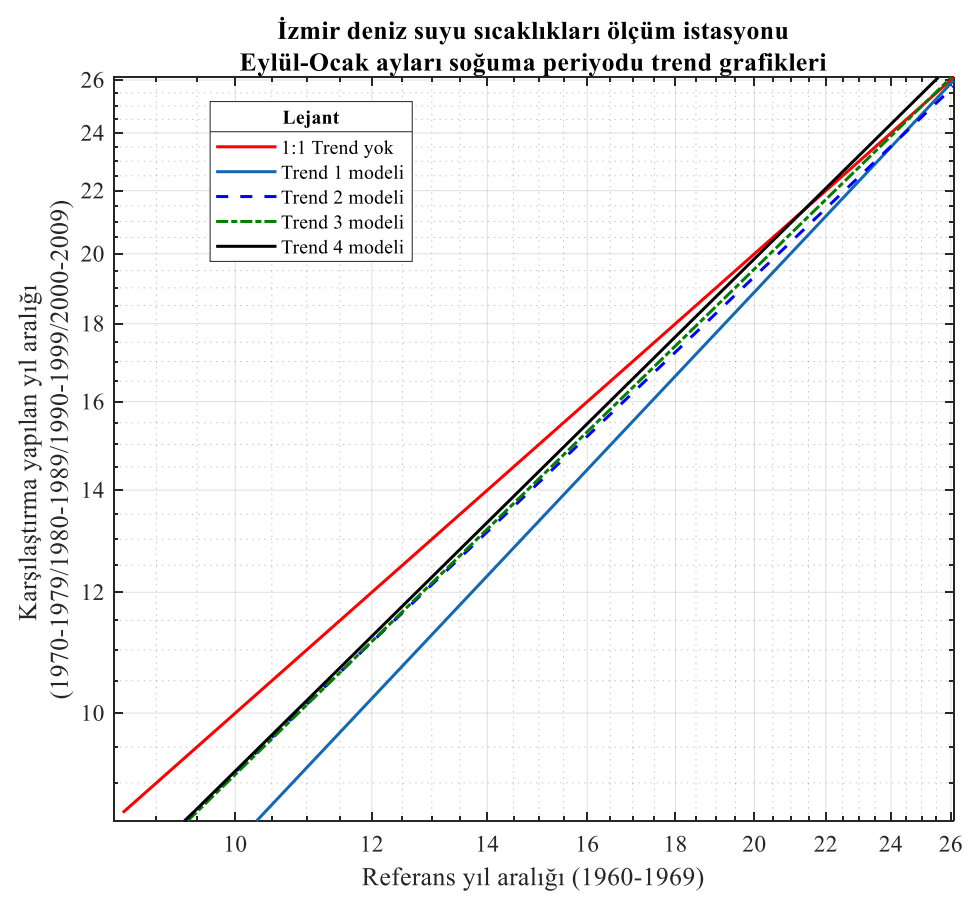

Şekil 7: Izmir deniz suyu sıcaklıklarının 1960-1969 referans yıl aralığına göre eğilimleri 
Şekil 6' da yer alan İzmir grafikleri üzerinden değerlendirmeler yapıldığında, 1960-1969 yıllarına göre azalan eğilim açıkça görülmektedir. Sadece Trend 4 modelinde sonbahar aylarına gelen sıcaklık değerlerinde küçük bir artış dışında genellikle azalan trend durumları görülmektedir.1970-1979 yılları deniz suyu sıcaklıkları 1960-1969 yıllarına göre oldukça soğuk geçmiştir.1970-1979 yılından sonra 2000-2009 yılına gelinceye kadar deniz suyu sıcaklıklarındaki artış Şekil 7'den kolaylıkla çıkarılabilmektedir. En soğuk dönem 1970-1979 yılları arasında gerçekleşmiştir. Ortalama doğruların eğimlerinden hareketle her 10 yıllık dönemle ilgili ayrıntılı kıyaslama, yorum ve değerlendirmelerde bulunulabilir.
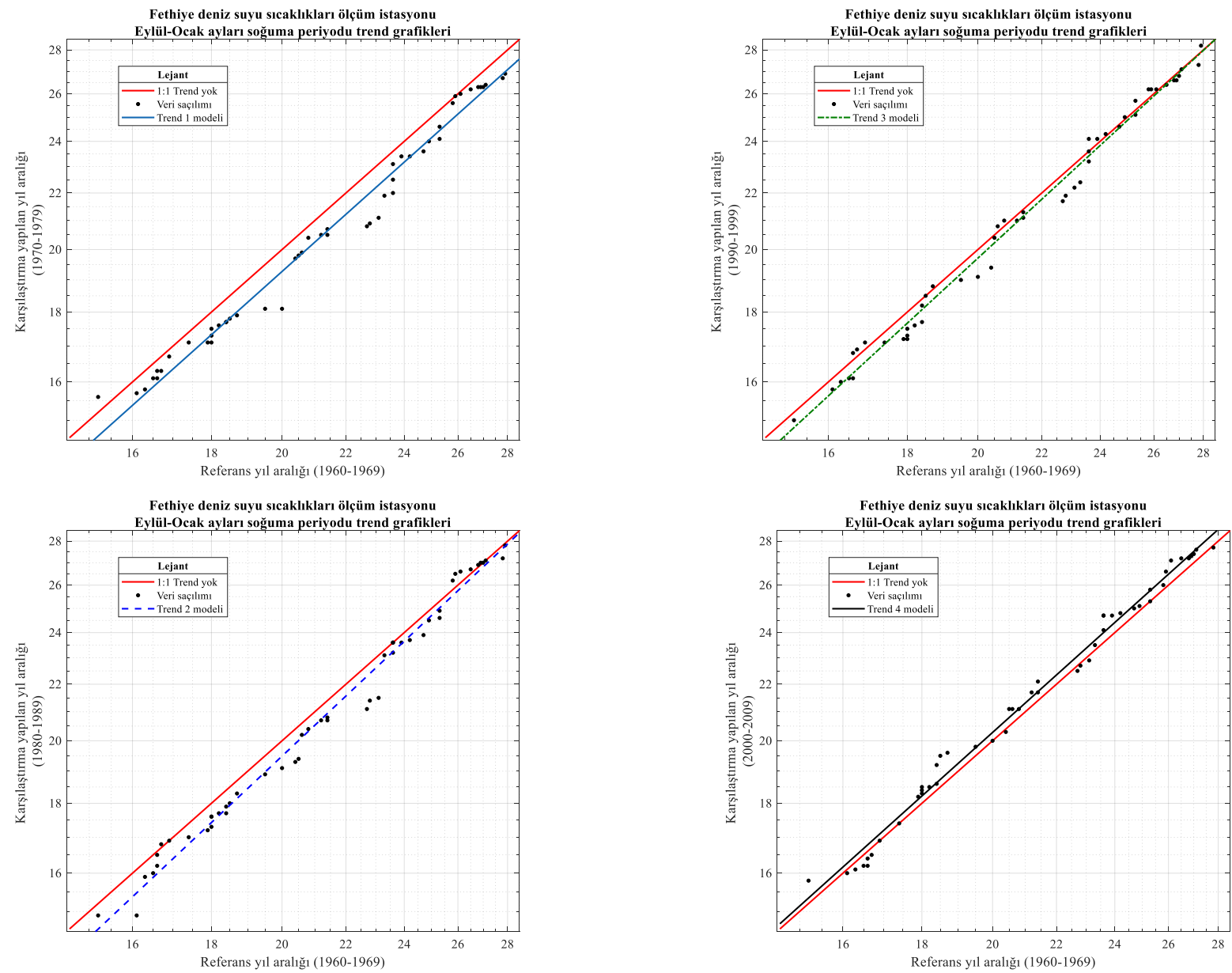

Şekil 8: Fethiye deniz suyu sıcaklıkları parçalı trend analizi grafikleri 


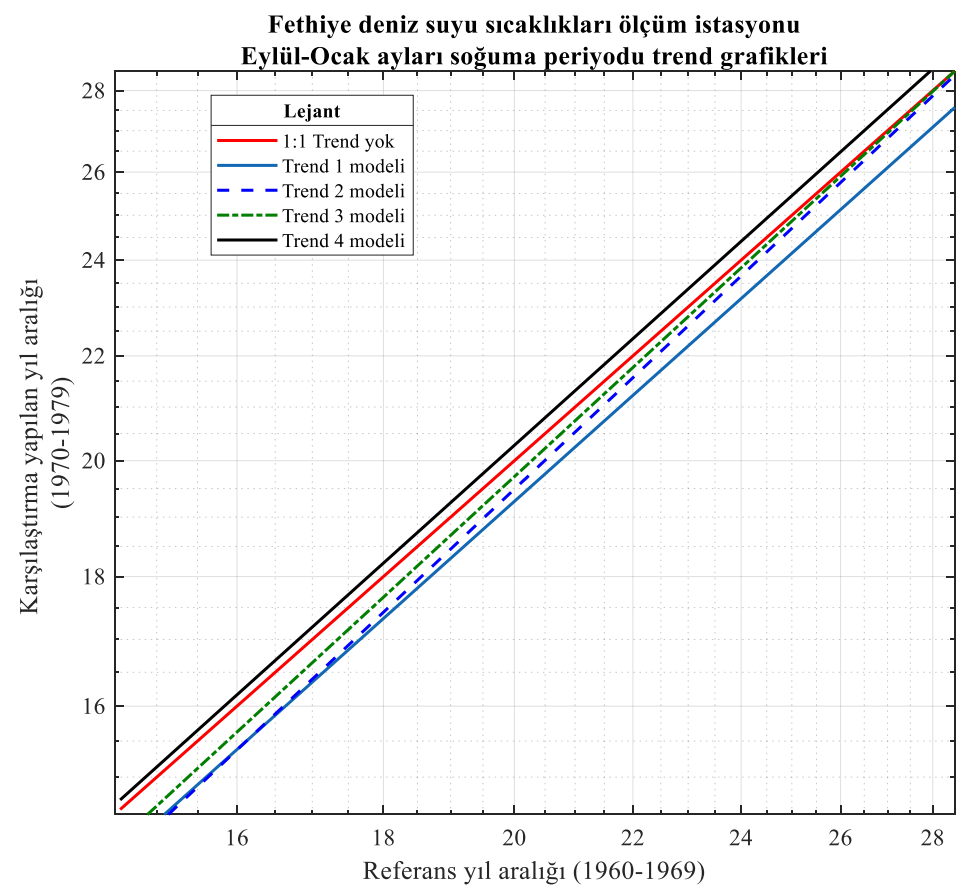

Şekil 9: Fethiye deniz suyu sıcaklıklarının 1960-1969 referans yıl aralığına göre eğilimleri

Akdeniz'de seçilen Fethiye istasyonu dikkate alındığında Şekil 8 ve 9'dan görüldüğü gibi 1960-1969 referans yıllarına göre 1970-2000 yılları arasındaki 30 yıllık sürede deniz suyu sıcaklıkları genelde ortalamada azalan trend içerisindedir. 2000-2009 yllına gelince ortalama eğilim artış yönünde gerçekleşmiştir. Soğuma dönemi tamamında veri saçılım geometrisine en uygun kuvvet fonksiyonları katsayıları ile genel ortalama trend durumları açıklanmıştır. Saçılımların geometrisine uygun matematik fonksiyonların kullanılabilmesi farklı yıllar arasında nesnel değerlendirme yapılabilmesini mümkün hale getirmiştir. 2000-2009 yılları deniz suyu sıcaklıklarının en fazla olduğu dönemdir. 1970-1979 yıllarından sonra deniz suyu sıcaklıkları sürekli bir şekilde artmıştır. Bunu açıkça Şekil 9'dan birbirini takip eden Trend 1-2-3-4 ortalama modelleri üzerinden anlamak mümkündür.

Akdeniz'in Türkiye kıyıları için deniz suyu sıcaklığının yaz aylarında en fazla olduğu İskenderun'a gelince, burada 2 alternatif süre için (1990-1999, 2000-2009) artış trendi, diğer 2 model süresi için ise azalan trend durumu görülmektedir. 2000-2009 yılları deniz suyu sıcaklıkları diğer 10 yıllık dönemlerden bariz şekilde artış yönünde farklılaşmıştır. 2000 öncesi dönemlerde deniz suyu sıcaklıklarında ortalama eğilim farklılıkları olsa da kayda değer bariz bir farklılık olduğu söylenemez.

İklim değişikliğinin en fazla hissedilmeye başladığı Akdeniz bölgesi için, 2000 yılından sonraki deniz suyu sıcaklıklarındaki artış eğilimi açıkça diğer dönemlerden farklıdır. Soğuma döneminde kış ve sonbaharda deniz suyu sıcaklıkları önemli ölçüde artmıştır. İstasyonların coğrafi konumlarına ve referans yıl aralı̆̆ına göre eğilim durumları bu çalışmada açıklandığı şekilde artış, azalış ve/veya trend yok şeklinde gerçekleşmiştir. Her bir istasyon için çifte logaritmik eksende hazırlanan YEÇ şablonlarına göre saçılımlar ve bu saçılımların ortalamaları kuvvet fonksiyonları eşitlikleri ile tanımlanmıştır. İstasyonlar için regresyon ile elde edilen kuvvet fonksiyonları katsayıları Tablo 4'de verilmiştir. Ortalama trendin nesnel olarak matematik eşitlikler ile tanımlanması sonrası yıllar arasında, trend karşılaştırması yapılmışıır. Genelde, Ege ve Akdeniz'de 1970 sonrası belirgin sıcaklık artışı ortaya çıkmıştı. Ayrıca eğilim araştırması için uygulanması düşünülen basit doğrusal regresyon için verilerin normal dağılıma uygunluğu Shapiro Wilk Testi ile sınanmıştır. Tablo 3'den görüldüğü gibi anlamlılık düzeylerinin $p<0.05$ olması sebebiyle hipotezler reddedilmiş ve istasyonlardaki dağılımların normal dağılıma uygun olmadıkları görülmüştür. Bu sebeple basit doğrusal regresyon ile belirlenecek eğilimler taraflı olacağı için regresyon yöntemi uygulanamamıştır. 


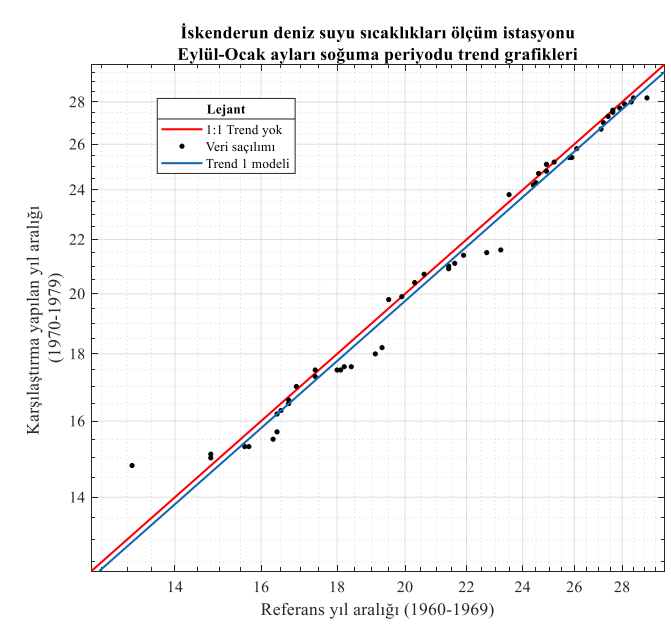

İskenderun deniz suyu sıcaklıkları ölçüm istasyonu

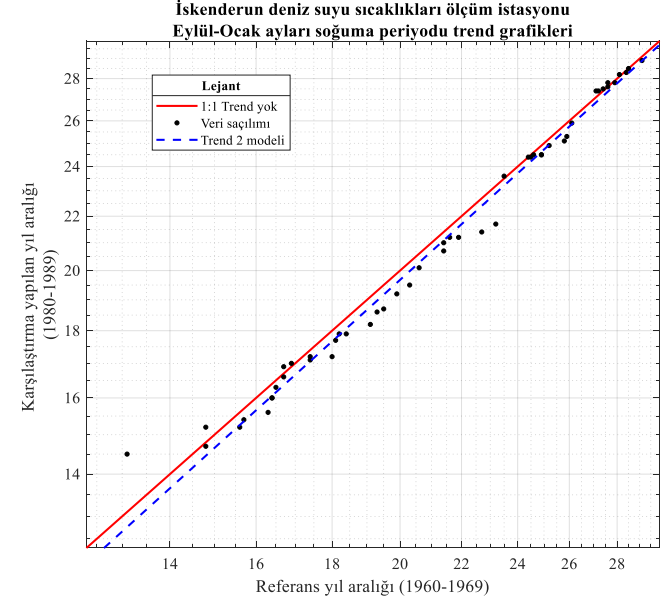

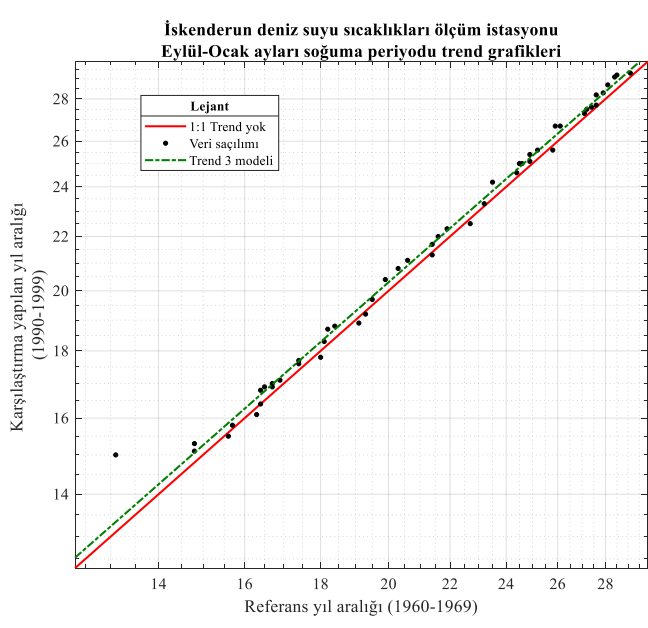

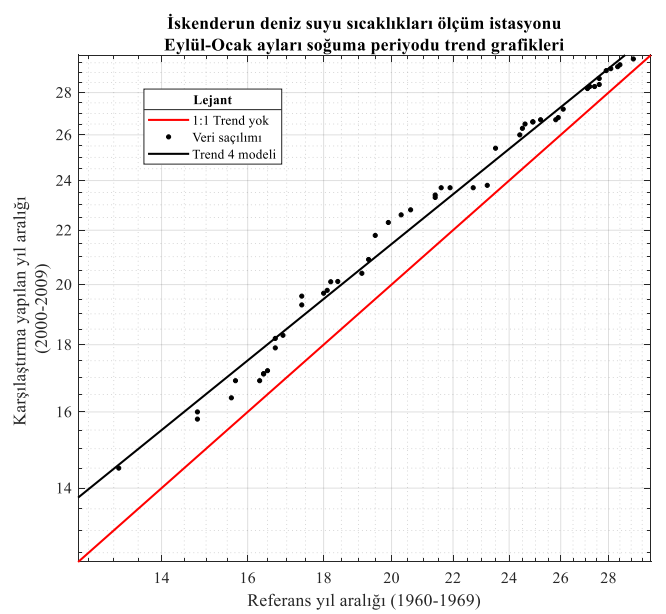

Şekil 10: İskenderun deniz suyu sıcaklıkları parçalı trend analizi grafikleri

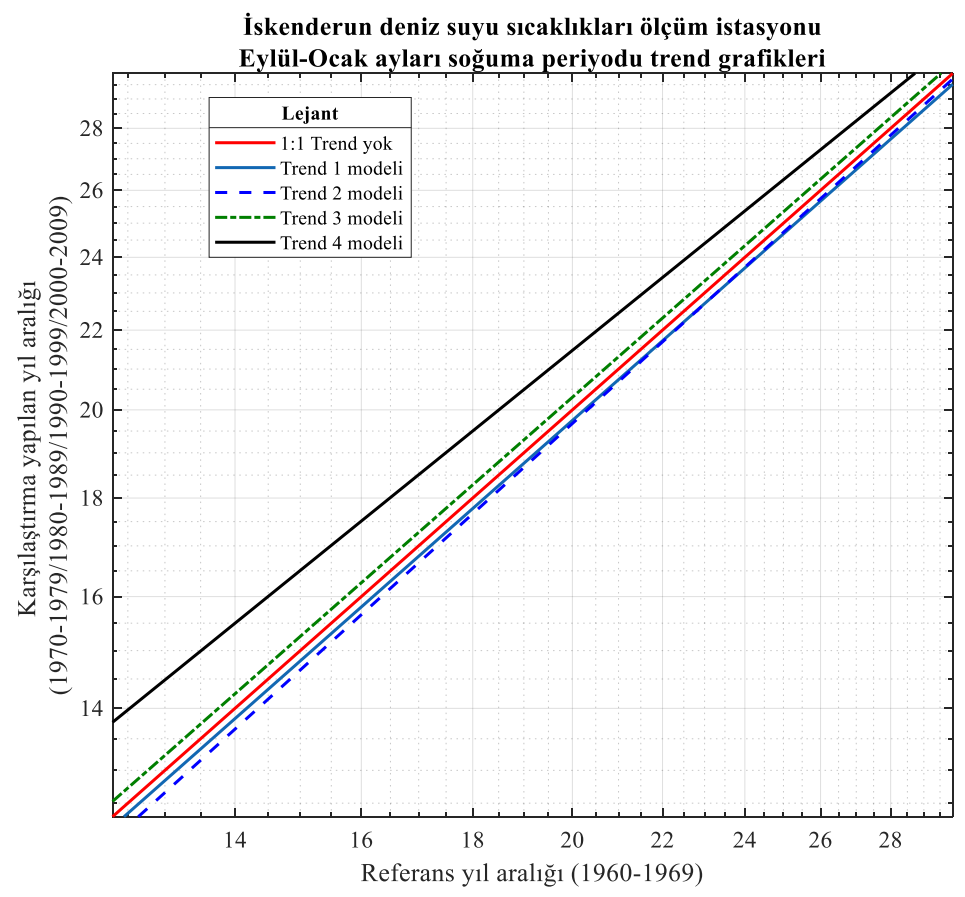

Şekil 11: Iskenderun deniz suyu sıcaklıklarının 1960-1969 referans yıl aralığına göre eğilimleri 
Tablo 3: SPSS programı ile Shapiro-Wilk testi istatistikleri

\begin{tabular}{cccc}
\hline \hline İstasyon İsmi & Kiy1 & Istatistik & Anlamlllık (p) \\
\hline İzmir & \multirow{2}{*}{ Ege } & 0.915 & .000 \\
Bodrum & & 0.947 & .000 \\
\hline Fethiye & \multirow{2}{*}{ Akdeniz } & 0.919 & .000 \\
İskenderun & & 0.914 & .000 \\
\hline \hline
\end{tabular}

Tablo 4: Seçilen istasyonların eğilim durumlarının matematik model parametreleri ve istatistikleri

\begin{tabular}{|c|c|c|c|c|c|c|}
\hline \multirow{3}{*}{ Kiyılar } & \multirow{3}{*}{ İstasyon İsmi } & \multicolumn{3}{|c|}{ Soğuma Periyodu } & \multicolumn{2}{|c|}{ (Eylül- Ocak) } \\
\hline & & \multicolumn{5}{|c|}{$y=a x^{b}$} \\
\hline & & $\mathrm{a}$ & $\mathrm{b}$ & $\mathrm{R}^{2}$ & SSE & RMSE \\
\hline \multirow{4}{*}{ 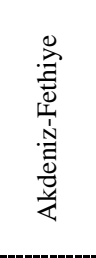 } & $\begin{array}{c}\text { Trend 1 modeli } \\
1960-1969 / 1970-1979\end{array}$ & 0.9326 & 1.011 & 0.983 & 11.57 & 0.491 \\
\hline & $\begin{array}{c}\text { Trend } 2 \text { modeli } \\
1960-1969 / 1980-1989\end{array}$ & 0.8079 & 1.063 & 0.987 & 9.85 & 0.453 \\
\hline & $\begin{array}{c}\text { Trend } 3 \text { modeli } \\
1960-1969 / 1990-1999\end{array}$ & 0.8722 & 1.041 & 0.99 & 7.528 & 0.396 \\
\hline & $\begin{array}{c}\text { Trend } 4 \text { modeli } \\
1960-1969 / 2000-2009\end{array}$ & 0.9645 & 1.017 & 0.99 & 6.702 & 0.3737 \\
\hline \multirow{4}{*}{ 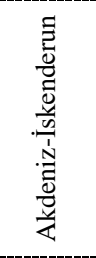 } & $\begin{array}{c}\text { Trend 1 modeli } \\
1960-1969 / 1970-1979\end{array}$ & 0.9904 & 0.999 & 0.9884 & 11.81 & 0.496 \\
\hline & $\begin{array}{c}\text { Trend } 2 \text { modeli } \\
1960-1969 / 1980-1989\end{array}$ & 0.9158 & 1.024 & 0.9904 & 10.17 & 0.4602 \\
\hline & $\begin{array}{c}\text { Trend } 3 \text { modeli } \\
1960-1969 / 1990-1999\end{array}$ & 1.035 & 0.993 & 0.994 & 5.97 & 0.3526 \\
\hline & $\begin{array}{c}\text { Trend } 4 \text { modeli } \\
\text { 1960-1969/2000-2009 }\end{array}$ & 1.389 & 0.9141 & 0.988 & 11.79 & 0.4956 \\
\hline \multirow{4}{*}{ 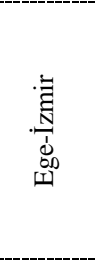 } & $\begin{array}{c}\text { Trend 1 modeli } \\
1960-1969 / 1970-1979\end{array}$ & 0.5172 & 1.201 & 0.989 & 14.47 & 0.549 \\
\hline & $\begin{array}{c}\text { Trend } 2 \text { modeli } \\
1960-1969 / 1980-1989\end{array}$ & 0.7618 & 1.079 & 0.989 & 11.75 & 0.495 \\
\hline & $\begin{array}{c}\text { Trend } 3 \text { modeli } \\
1960-1969 / 1990-1999\end{array}$ & 0.7233 & 1.1 & 0.991 & 10.86 & 0.4757 \\
\hline & $\begin{array}{c}\text { Trend } 4 \text { modeli } \\
\text { 1960-1969/2000-2009 }\end{array}$ & 0.7025 & 1.115 & 0.992 & 10.49 & 0.4674 \\
\hline \multirow{4}{*}{ 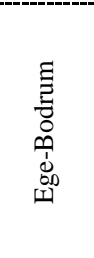 } & $\begin{array}{c}\text { Trend 1 modeli } \\
1960-1969 / 1970-1979\end{array}$ & 1.299 & 0.903 & 0.981 & 5.227 & 0.33 \\
\hline & $\begin{array}{c}\text { Trend } 2 \text { modeli } \\
1960-1969 / 1980-1989\end{array}$ & 0.874 & 1.035 & 0.985 & 5.556 & 0.34 \\
\hline & $\begin{array}{c}\text { Trend } 3 \text { modeli } \\
1960-1969 / 1990-1999\end{array}$ & 0.6892 & 1.117 & 0.989 & 4.537 & 0.31 \\
\hline & $\begin{array}{c}\text { Trend } 4 \text { modeli } \\
1960-1969 / 2000-2009\end{array}$ & 0.6824 & 1.131 & 0.987 & 5.846 & 0.349 \\
\hline
\end{tabular}

\section{Sonuç}

İklim değişikliği ile çevre, hidroloji ve su kaynaklarının konusu olan verilerde ortaya çıkan değişimlerin belirlenmesi için. yapılan araştırmaların sayısı son dönemde aşırı artış göstermektedir. Klasik trend analizi yöntemleri kullanılarak ortaya konulan model çözümleri fazlaca ön şart ve varsayım nedeniyle işlenmemiş verilerdeki eğilimlerin belirlenebilmesi için kolaylıkla kullanılamamaktadır. Nitekim bu çalışmada merak edilen eğilimlerin belirlenebilmesi için kullanılan verilerin normal dağılıma uymaması sebebiyle basit doğrusal regresyon yöntemi kullanılamamıştır. Bunun aksine herhangi bir varsayıma dayanmayan uygulaması son derece basit parçalı Yenilikçi Eğilim Çözümlemesi (YEÇ) ile eğilim durumları. geometrileri ve sonrasında ortalama eğilimlerin fonksiyonel bağıntılarının matematik ifadeleri bu araştırma çalışmasında kullanılan yöntem aracılığıyla ortaya çıkarılmıştır. Bu çalışmada soğuma dönemine ait trendlerin kuvvet fonksiyonu ile modellenmesi sayesinde belirlenen istasyonlar birbiriyle kıyaslanmıştır. Isınma dönemindeki trend değişimlerinde ani sıçrama ve geçişler görülmektedir. Bu sebeple. benzer bir matematik modelleme kullanılamamıştır. Aylar arasındaki geçişler göz önünde bulundurularak. 1sınma için yeni bir yaklaşımda bulunulabileceği düşünülmektedir Model sonuçları üzerinden genel bir değerlendirmede bulunulduğunda. 2000 sonrası deniz suyu sicaklıklarında 1sınma açıkça tüm istasyonlarda görülmektedir. 1970 y1lından sonra deniz suyunun sürekli olarak 1sınma trendinde olduğu modelleme sonuçları incelendiğinde görülmektedir. En belirgin ve önemli artış İskenderun'da 2000-2009 döneminde gerçekleşmiştir. Ege'de genelde 1960-1969 periyodu en sıcak dönem olarak ölçülmüştür. Ayrıca genelde 1960-1969 referans yıl aralığına göre deniz suyu sıcaklıklarında bir azalan eğilim söz konusudur. Beklenilmeyen ilk yıllardaki kayıtlı verilerden kaynaklı bu durumun sebebi açıkça ortaya konulamamıştır. 


\section{Kaynaklar}

Al-Rashidi T.B., El-Gamily, H.I., Amos, C.L., Rakha K.A., (2009), Sea surface temperature trends in Kuwait bay, Arabian Gulf, Natural Hazards, 50(1), 73-82.

Barbosa S.M., Andersen O.B., (2009), Trend patterns in global sea surface temperature, International Journal of Climatology, 29(14), 2049-2055.

Cane M.A., Clement A.C., Kaplan A., Kushnir Y., Pozdnyakov D., Seager R., Murtugudde R., (1997), Twentieth-century sea surface temperature trends, Science, 275(5302), 957-960.

Chu C., Jones N.E., Piggott A.R., Buttle J.M., (2009), Evaluation of a Simple Method to Classify the Thermal Characteristics of Streams Using a Nomogram of Daily Maximum Air and Water Temperatures, North American Journal of Fisheries Management, 29(1993), 1605-1619.

Dabanlı İ., Şen Z., Yeleğen M.Ö., Şişman E., Selek B., Güçlü Y.S., (2016), Trend assessment by the innovative-Şen method, Water Resour Manag, 30(14), 5193-5203.

Deser C., Alexander M.A., Xie S., Phillips A.S., (2010), Sea surface temperature variability: Patterns and mechanisms, Annual Review of Marine Science, 2(1), 115-143.

Dogan M., Cigizoglu H. K., Sanli D.U., Ulke A., (2014), Investigation of sea level anomalies related with NAO along the west coasts of Turkey and their consistency with sea surface temperature trends, Theoretical and Applied Climatology, 121(1), 349-358.

Gil-Alana L.A., (2015), Linear and segmented trends in sea surface temperature data, Journal of Applied Statistics, 42(7), 1531-1546.

Goikoetxea N., Borja Á., Fontán A., González M., Valencia V., (2009), Trends and anomalies in sea-surface temperature observed over the last 60 years within the southeastern Bay of Biscay, Continental Shelf Research, 29(8), 1060-1069.

Gómez-Gesteira M., Decastro M., Alvarez I., Gómez-Gesteira J.L., (2008), Coastal sea surface temperature warming trend along the continental part of the Atlantic Arc (1985-2005), Journal of Geophysical Research: Oceans, 113(C4), C04010:1-9.

Gómez-Gesteira M., Gimeno L., Decastro M., Lorenzo M.N., Alvarez I., Nieto R., Gómez-Gesteira J.L., (2011), The state of climate in NW Iberia, Climate Research, 48(2/3), 109-144.

Güçlü Y., (2013), Sea surface temperature anomalies along the Black Sea Region coast of Turkey (1971-2010 period), Journal of Human Sciences, 10(1), 863-896.

Güçlü Y.S., (2016), Comments on "Comparison of Mann-Kendall and innovative trend method for water quality parameters of the Kizilirmak River. Turkey (Kisi and Ay. 2014)" and "An innovative method for trend analysis of monthly pan evaporations (Kisi. 2015)", Journal of Hydrology, 538, 878-882.

Güçlü Y.S., Şişman E., Yeleğen M.Ö., (2018), Climate change and frequency-intensity-duration (FID) curves for Florya station Istanbul, Journal of Flood Risk Management, 11(S1), S403-S418.

Güçlü Y.S., (2018), Alternative Trend Analysis: Half Time Series Methodology, Water Resources Management, 32(7), $2489-2504$.

Haktanir T., Citakoglu H., (2014), Trend independence stationarity and homogeneity tests on maximum rainfall series of standard durations recorded in Turkey, J. Hydrol. Eng., 19(9), doi:10.1061/(ASCE)HE.1943-5584.0000973.

Haylock M.R., Peterson T.C., Alves L.M., Ambrizzi T., Anunciação Y.M.T., Baez J., Vincent L.A., (2006), Trends in total and extreme South American rainfall in 1960-2000 and links with sea surface temperature, Journal of Climate, 19(8), 1490-1512.

Houghton JT., Filho LGM., Callander BA., Harris N., Kattenberg A., Maskell K., (1996), Climate Change 1995: The Science of Climate Change, Cambridge University Press: Cambridge. UK.

Johannessen O.M., Bengtsson L., Miles M.W., Kuzmina S.I., Semenov. V.A., Alekseev G.V., Cattle H.P., (2004), Arctic climate change: Observed and modelled temperature and sea-ice variability. Tellus A, 56(4), 328-341.

Jonsdottir J.F., Jonsson P., Uvo C.B., (2006), Trend analysis of Icelandic discharge. precipitation and temperature series, Nord. Hydrol., 37(4-5), 365-376.

Kadioğlu M., Şen Z., Gültekin L., (2001), Variations and trends in Turkish seasonal heating and cooling degree-days, Climatic Change, 49(1), 209-223.

Kaplan A., Cane M.A., Kushnir Y., Clement A.C., Blumenthal M.B., Rajagopalan B., (1998), Analyses of global sea surface temperature 1856-1991, Journal of Geophysical Research, 103(C9), 18567-18589.

Kazmin A.S., Zatsepin A.G., (2007), Long term variability of surface temperature in the Black Sea and its connection with the large scale atmospheric forcing, J Mar Syst, 68, 293-301.

Markus M., Demissie M., Short M., Verma S., Cooke R., (2014), Sensitivity Analysis of Annual Nitrate Loads and the Corresponding Trends in the Lower Illinois River, Journal of Hydrologic Engineering, 19(3), 533-543.

Moron V., Vautard R., Ghil M., (1998), Trends. interdecadal and interannual oscillations in global sea-surface temperatures, Climate Dynamics, 14(7), 545-569.

Ozgenc A., (2017), A Investigation of sea level trends and the effect of the north atlantic oscillation (NAO) on the black sea and the eastern mediterranean sea, Theor Appl Climatol, 129(1-2), 129-137.

Park K., Lee E., Chang E., Hong S., (2015), Spatial and temporal variability of sea surface temperature and warming trends in the yellow sea, Journal of Marine Systems, 143, 24-38.

Revelle R., (1983), Probable future changes in sea-level resulting from increased atmospheric carbon dioxide, National Academy Press. Changing Climate. 8. Chapter, Washington.

Robertson R., Visbeck M., Gordon A.L., Fahrbach E., (2002)., Long-term temperature trends in the deep waters of the Weddell Sea, Deep-Sea Research Part II, 49(21), 4791-4806.

Saplioglu K., Kilit M., Bekir Y.K., (2014), Trend Analysis of Streams in the Western Mediterranean Basin of Turkey, Fresenius Environmental Bulletin, 23(1A), 313-324.

Sen Z., (2012), Innovative trend analysis methodology, J. Hydrol. Eng, 17 (9), 1042-1046.

Sen Z., (2014), Trend identification simulation and application, J. Hydrol. Eng, 19 (3), 635-642.

Shaltout M., Omstedt A., (2014), Recent sea surface temperature trends and future scenarios for the Mediterranean Sea, Oceanologia, 56(3), 411-443. 
Timbadiya P., Mirajkar A., Patel P., Porey P., (2013), Identification of trend and probability distribution for time series of annual peak flow in Tapi Basin India. ISH Journal of Hydraulic Engineering, 19(1), 11-20.

Zveryaev I.I., (2015), Seasonal differences in intraseasonal and interannual variability of Mediterranean Sea surface temperature, Journal of Geophysical Research C: Oceans, 120(4), 2813-2825. 